\title{
THE WEST AND ITS OPIUM IMPORT IN CHINA
}

The image of the Chinese was not very favorable in the Western perception to use an understatement. What was China's own contribution to the world's Opium Problem apart from providing the largest number of opium consumers at the end of the 19th-century? To qualify this last question immediately, we can reveal that Chinese already around 1830

routinely depicted [opium smokers] as physically and mentally decrepit, with a skeletal frame, a grey complexion, weak stamina, stained teeth, diminishing willpower and a lack of incentive to work. ${ }^{1}$

Many missionaries used similar words at the end of the century in their propaganda directed at the homeland to coax funds for the poor missions in such miserable countries like China.

Around 1830, these opium victims were hated because they exposed the weakness of the Qing state, and they permanently demonstrated the Chinese defeat, the serious humiliation by the 'foreign devils': Opium was the poison of the West. Whoever supported these criminal Western foreigners was himself a criminal. Consumption of the poison was no less a crime than helping these foreigners to distribute the opium or assisting them in other ways (from money changing to translations). It is difficult to condemn Chinese governments or local officials for these reactions.

There is, furthermore, the classic reaction of all shopkeepers and some historians: "The Chinese wanted to buy the stuff itself, so we delivered!" This is an insufficient as well as a demagogic answer: "The Chinese" do not want anything, only specific Chinese people do. It presupposes preliminary knowledge available only to the sellers, and products available only to the importers. Aside from the fact that both sellers and importers knew perfectly well how poisonous the stuff was.

Still, it is clear enough that too many Chinese were eager to buy opium so that "China" became synonymous with Opium. This reached such a degree that some Chinese started cultivating poppies, which contributed to the perception in the West known as the Yellow Menace. In all cases,

1 L. Kwong, p. 1485; for the same kind of depiction from 1895 see R. K. Newman (1995), p. 766 with many other examples in Idem, note 3 . 
however, opium 'was intricately involved with the unfathomable interaction between China, India, Britain, the United States, France, and other European nations ...'2

Under the impact of the present Chinese economic domination, the West has started to look more thoroughly into this Chinese opium history. Some consensus about the Chinese victim position is being hesitatingly accepted among serious Western scholars. ${ }^{3}$ How the Chinese handled this problem themselves mostly remains unclear. It is, therefore, the time to look at details of the Opium Problem from the victims' viewpoints. How active were Chinese producers, traders and mafia, and how were they treated and dealt with by the Chinese governments mainly in the period $1900-1950$ ?

The Chinese producers and distributors knew perfectly well how unlawful and morally objectionable their work was in official Chinese eyes and discourses. They helped the foreigners to spread the Opium Problem across the country after the Opium Wars were lost. The large international context in which they operated must be stressed, and this made a fundamental distinction necessary between the Chinese in China and those living elsewhere in Asia (see ch. 25). Sometimes they interacted, which gave the Chinese side of the Opium Problem a nearly universal Asian profile. Below, remarks about this context will precede the main subject of this part, which is the Chinese opium production and consumption. Who can better describe this mutual relationship than the man, who-as representative of the British occupier-had to play a remarkable intermediary role?

2 K. McMahon, p. ix.

3 One has to stress the word 'serious'. A Dutch historical journal published recently an article from its 'correspondent' in China, B. de Groot (Historisch Nieuwsblad, September 2010, p. 27). In China it was until 2009 normal to come up with a massive number of 'colonial clichés' . But 'now there is an economic crisis and China needs Europe desperately', China even forgets the anniversary of the Second Opium War. However, the schoolbooks still tell these 'colonial clichés'. An example of this is the following sentence, according to this expert: 'In October 186o the bandits from the West imposed a dishonest treaty on the corrupt Qing-government ... To enrich Europe the Chinese people had to become addicted.' Long before 1860 in the British Parliament, judgements about the Opium War were couched in similar language, while Multatuli wrote about a 'Dutch robber state'. Even the robbers themselves, like Warren Hastings, thought of the opium trade as a kind of criminal act (see above). For De Groot all those stories are only told 'to blacken Europe'. What is in crisis here? 


\section{A British Inspector ...}

Who could better judge the opium situation in China than the top representatives of those who produced and imported the opium? A most energetic example was the British diplomat, traveler, writer and inspector, Sir Alexander Hosie (1853-1925). He made several long trips through many provinces of China, visited the same locations several times, and reported in many books about the differences and similarities, mostly in a dry accountants' language. Hosie was also a member of a delegation to the Shanghai International Opium Commission (1909). He occupied a responsible position. Largely based on Hosie's positive advice and unconfirmed investigations, the British government was practically obliged to officially stop the lucrative opium imports from India (1917). However, the "Perfidious Albion" cynically built in loopholes in its treaties with China.

The report which is important for our endeavors is Hosie's two-volume On the Trail of the Opium Poppy (1914). They sketch journeys through six provinces, partly still unexplored, which were the chief centers of Chinese opium production. The results of this were published earlier in Parliamentary Papers around 1912. Two long appendices in this work explain the inception, organization and methods of the anti-opium crusade; the second is a very useful summary of all the data he had gathered in the six most important opium provinces, Shansi, Shensi, Kansu, Szechuan, Yunnan and Kueichou.

The introduction to the first appendix is interesting, because it tells how it "all" started: during a British invasion into Tibet in 1903/04. The British exerted lethal force with their new Maxim machineguns against poorly armed Tibetans. A treaty was imposed on Tibet by the British occupier, but the British were not satisfied by this: 'the seal of the Amban, the representative of China-the suzerain of Tibet' was absent. This led to new negotiations between the British Empire and China. ${ }^{4}$

A special Chinese Envoy was send to Calcutta (September 1904) to negotiate with the Government of India. During this visit the Chinese Envoy, T'ang Shao-yi, 'derived the impression that India was prepared to dispense with her opium revenue'. Hosie continues with the remarkable and symptomatic sentence that this Envoy

\footnotetext{
4 See A.Porter (ed.), the contribution of R. Moore, p. $434 \mathrm{ff}$. and the contribution of J. Osterhammel in Idem, p. 160 ff.. See also the Wikipedia article "Expedition to Tibet".
} 
on his return to Peking ... informed his Government that it was the Chinese craving for the drug, and not England's desire to force it upon China, which was responsible for the continuance of the traffic in Indian opium. Thus was initiated the campaign against the cultivation of the poppy and the consumption of opium in China ...5

From every point of view, this is breathtaking information! A very British man like Hosie, and one of the few opium experts, writes this baldly without any remark. Whether Tang Shao-yi made a bold diplomatic manoeuvre or not by spiriting away the pivotal role of the British in addicting the Chinese, the fact is that - in hindsight - this became an opening move to solve one of the most complicated, large-scale and fundamental questions of a society. It is unbelievable that a Chinese Envoy would inform his own government of such a lie. One can only imagine that the British told the envoy to inform his government that no agreement would be possible if any accusations whatsoever were launched against the British (they could easily lead to very costly compensations in this Opium Case). In short, it would be worthwhile for someone to look in the archives again for the background of the negotiations about Tibet between China and the British.

In my view, the British Balfour government's arrogance and ignorance merged Curzon's geopolitical speculations about Russia's aims in China, and the interests of Calcutta's cotton and opium merchants to make a Tibetan deal with China. In the long term, the British could have aimed at a Western land route into China (a rather utopian aim militarily), while intimidating Russia from doing the same. Both perceived China as a colossus on feet of clay. ${ }^{6}$ The Chinese interest must have involved negating its dependence on Britain (and foreigners in general), which largely hinged on the British-Indian opium business.

In any case, the Chinese were very quick to exploit the situation. An Imperial Decree (September 1906) was issued, expressing the worries of the Emperor about the ruinous effects of the opium in his country and commanding 'that within a period of ten years the evils arising from foreign and native opium be equally and completely eradicated'. ${ }^{7}$

5 A. Hosie, vol. 2, p. 191, 192. The quotations below are from the following pages.

${ }^{6}$ Both calculated their political future also in regard to Japan, which had already won a Chinese-Japanese War. The Russians wanted to secure their presence in the Far East (Vladivostok, Port Arthur); the Japanese were certainly the most aggressive as described in ch. 27 .

7 Quoted in Idem, p. 192. See also K. Chimin Wong, W. Lien-Teh, p. 566, 603. 
Two months later a series of detailed proposals were submitted that practically aimed at a strong central government grip on the poppy fields, production, consumers and trade. Contrary to similar attempts in the Dutch or French colonies, the Chinese central government really wanted to eradicate the entire poppy culture. The proposals did not intend to establish a state opium monopoly, as is often claimed. ${ }^{8}$ Some officials probably put forward such a plan, but that was not only contrary to several 1906 proposals, the existence of the international settlements or Hong Kong made such a scheme impossible. Peking needed to destroy the poppy culture as part of the foreign occupation. That is what happened as testified by Hosie and others.

The main difficulty was, of course, how to deal with the huge BritishIndian opium interest of the main occupier. In article 10 an arrangement with the British was proposed

with a view to effecting an annual decrease within the next few years of the import of foreign opium, pari passu with the decrease of native opium, so that both may be absolutely prohibited by the expiry of the time-limit of ten years. Besides India opium, the drug is also imported from Persia, Annam and the Dutch Indies in no small quantities. In the case of Treaty Powers negotiations should similarly be entered into with their representatives in Peking to effect the prohibition of such import ... ${ }^{9}$

In stronger wording, the article continues to talk about 'morphia ... the effects of which are even more injurious than those of opium itself..' and about the need to ban also the 'instruments for its injection'.

A new series of concrete proposals were submitted (January 1907) to serve as a basis for negotiations concerning the import and taxation of Indian opium (raw and prepared), the consumption in the foreign settlements in China, and the import of morphia: reduction of Indian import by $10 \%$ every year starting from 1907; duties on native and Indian opium must be raised (but since the Indian opium is twice as strong as the native one, the tax increased twice as much); the large Hong Kong prepared opium stock must be taxed with a very high duty, if its import into China cannot be prevented; prohibition of selling opium in brothels, tea-shops, hotels, opium dens, restaurants or other public resorts in the foreign settlements; prohibition of export of morphia to China including the syringes or injection needles.

\footnotetext{
8 For instance, recently by B. de Groot (previous note 3 ).

9 Quoted in A. Hosie, vol. 2, p. 203, 204.
} 
Of course, they were followed by counter-proposals from the BritishIndian government: instead of reducing the import into China, they would be willing to reduce by one-tenth the annual export to China for three years (from 1901-5 this was 67,000 chests, of which China took $51,000)$. And they promised also that if China diminished its own production and consumption, they would 'undertake to continue in the same proportion this annual diminution of the export after the three years in question'. 10

His Majesty's Government wanted to receive additional information from Peking on several other minor issues. Only the gist of this first counter-reaction is important here: we, the British, will accept many things if you, the Chinese, do what you promised to do. This seems logical, probably reasonable, but this was not the case: it was only reasonable to assume that the Chinese could not entirely abolish opium, so the British-Indian import could continue anyway. It would have been logical if the British opium perpetrator had proposed a scheme for stopping its exports, since it had earned at least a billion pounds in this opium trade (see ch. 6 and 7), after the international outcry about its opium performance, and since the abolition of slavery had been realized a century earlier.

Several other proposals were exchanged. A new aspect was that the government of the United States interfered with a proposal to establish a joint International Commission to investigate the opium trade (May 1908). This had the effect that the Chinese-British negotiations could no longer remain secret, but had to proceed in the light of the media and public and that for the first time statistical data were gathered about the Opium Problem in many countries.

They formed the preparations for the rather famous Shanghai Conference (1st to 26th February 1909), the start of a long series of international conferences which still continues today, in fact. The good news for the Chinese was that a period of ten years was accepted after which the British import of opium was fully stopped; the bad news was that in a new agreement with China (May 1911), England put so many conditions and demands on the table that it gives the impression the British wanted to blow up the whole affair." ${ }^{11}$

In the ten long articles plus annex of this latter agreement, the British demanded that the diminishing of the Chinese opium production should

10 Idem, p. 208. The Persian-Turkish opium import was fixed at only 1,125 piculs annually (Idem, p. 212, 213), negligible compared to the British.

11 The literary text of this agreement is given in Idem, p. 220-227. 
go 'in the same proportion as the annual export from India' for seven years; this export will only cease 'if clear proof is given of the complete absence of production of native opium in China'; it did not permit closure of the Canton and Shanghai ports for Indian opium until the very end of the whole process; India will stop its export only when China 'has effectively suppressed the cultivation and import of native opium' into any Chinese province; on confirmation of the agreement, China will immediately withdraw 'all restrictions ... on the wholesale trade in Indian opium ... and ... all taxation on the wholesale trade ...'; British officials must be allowed to continuously investigate the Chinese diminution of cultivation and 'their decision as to the extent of cultivation shall be accepted by both parties to this agreement'; and so on.

The important British official carrying out this controversial work was the inspector, Sir Alexander Hosie. With a stiff upper lip, he produced an agreement like this without any comment. Even worse, at the end he put his "signature" below the following repetition of the lie the Chinese Envoy, T'ang Shao-yi, tried to sell to his government in 1904 (according to Hosie):

Thus was taken the first step towards the eradication of an evil for which the Chinese themselves have alone been responsible all along, and which a policy of drift has permitted to be widespread. The evil had its origin in China itself, and I feel bound to say that but for the help of Great Britain ... the progress that we see to-day ... would not have been realized. ... The Government of China ... has recognized that assistance, and repeatedly expressed its gratitude to the British Government. ${ }^{12}$

Indeed, officially, there came an end to the Indian-China opium relationship. This was a rather abstract result, because many concurrent events of magnitude happened, including the abdication of the Empress and the start of something like a republic, which made this end different than the result of all previous negotiations.

The fate of Hosie is probably symptomatic of this. How often he complained about the false estimations made by other experts! In the second long appendix in which he described his voyages through six Chinese opium provinces, his own investigations were as superficial as all previous ones. Without any doubt, he made interesting and sometimes useful observations, but mostly he simply reproduced the opinions of missionaries. Generally, he provided a poorly amateurish performance.

12 Idem, p. 231. 
For example, Hosie visited Szechuan in January 1910, the province with the largest opium production, claimed to be not less than 238,000 piculs in 1906, which was reduced to 159,000 two years later. Hosie informs us further that the opium arrivals in 1910 in Ichang, the Yangtsze port, still amounted 28,370 piculs. In fact, during his trip a few days later 'I ascertained that poppy cultivation had entirely ceased after the season of 19081909.' 13

Newman was not surprised about this mystery as he read from Hosie that in Szechuan now 'hardly a stalk of poppy could be found'. ${ }^{14}$ The patriarchal Sir Alexander could not avoid adding the very British comment that China now was raised 'with all her faults in the estimation of the civilized world': a new attempt was being made to transform victims into perpetrators. Indeed, in these crucial years a serious change took place, which can best be shown in the next table concerning the opium and other imports.

Table 46. Percentage Distribution of China's principal Imports, 1870-191015

\begin{tabular}{lcccccc}
\hline Years & $\begin{array}{c}\text { total value (HK } \\
\text { taels x 1,000) }\end{array}$ & $\begin{array}{c}\text { Opium } \\
\%\end{array}$ & $\begin{array}{c}\text { Cotton piece } \\
\text { goods \% }\end{array}$ & $\begin{array}{c}\text { Cotton } \\
\text { yarn \% }\end{array}$ & $\begin{array}{c}\text { Kerosene } \\
\%\end{array}$ & $\begin{array}{c}\text { Machinery } \\
\%\end{array}$ \\
\hline 1870 & 63693 & 43 & 28 & 3 & --- & --- \\
1880 & 79293 & 39 & 25 & 5 & --- & --- \\
1890 & 127093 & 20 & 20 & 15 & 3 & 0,3 \\
1900 & 211070 & 15 & 22 & 14 & 7 & 0,7 \\
1910 & 462965 & 12 & 15 & 14 & 5 & 2 \\
\hline
\end{tabular}

It was about 70 years earlier when this "civilized" world smuggled opium to addict China on a large scale in favor of a few British soldiers, bureau-

13 Idem, p. 270. The interpretation or use of Hosie's judgments is still ambiguous, even by a fine historian like McCoy; see his contribution to A. McCoy, A. Block (ed.), p. 245 . Although he is clearly and rightly analyzing his case from the perspective of European colonialism as the creator of mass addiction, poppy cultivation and mass promotion of opium, the consequences of this are not followed with the same rigor. For instance, he (like all historians) presumed that the opium business was largely legal (Idem, p. 238). This was, however, only in the perception of the colonialists: from the start until the end, many if not most indigenous leaders protested against this opium trade. It is, furthermore, ahistorical and rather irrelevant to trace the use of opium back to several millennium B.C. (Idem, p. 239 ff.).

14 R. K. Newman (1989), p. 548.

15 A. Feuerwerker, p. 49. I have rounded the figures. The table is larger, but that is not very relevant here. One must realize, however, that in absolute terms the 1870 import concerns 27, 388,00o taels and in 1910 it is twice as much, 55,556,00o taels. The cotton piece goods come from Lancashire; yarn and opium from India. 
crats in India and England, and opium criminals like the Sassoons, Jardines, etc. The majority of the 19th-century opium was the single most important Chinese import. Only in the 1890 s was it surpassed by cotton piece goods. Whatever Hosie and others stated about the competing Chinese opium production, in these years apparently not a gram of Chinese opium was exported. Tea and silk remained the largest export goods. ${ }^{16}$

The actual Chinese defense against the opium assault was a direct follow-up of the earlier defense under the spectacular leadership of Commissioner Lin Zexu.

Now, at the end of the Indian-British-Chinese opium relationship (February 1918), a British gunboat manoeuvred in a remarkable way along the coast, and opium was again burned by Chinese officials. They also suggested that the opium stocks of the foreign merchants or governments should be repatriated to India from which they were sent. Apart from government actions, there were substantial anti-opium protests-largely identical with anti-British and anti-foreigner opposition - which brought people into the streets. The highest British diplomat in China, Jordan, eager to get opium off the British diplomatic agenda as quickly as possible, now supported this Chinese suggestion because the

spontaneous withdrawal of the stocks would produce an excellent impression and be a just and generous act which would form a fitting end to a trade which has become a moral anachronism. ${ }^{17}$

Indeed, the time for a luxury existence of foreigners in China was running out. The Chinese had to put up with their provocative behavior until the end of World War II. The Chinese opium drama remained spectacular until the end. The gradual British retreat, which coincided with the abdication of the Empress and the start of the Republican period, had many consequences.

As in the beginning of the opium game, the largest opium profiteers, the Sassoons, made fabulous gains again: prices rose from about 3000

16 The value of the tea export in 1870 is $27,647,500$ taels, and in 1910 it is $38,083,000$ taels; for silk these figures are 21,565,050 taels and 95,208,250 taels, respectively. Generally, in nearly all those years, China had a negative import-export balance with mainly the UK (British Empire). Also in this respect, the exploitation was going on until long after 1900. See Idem, table 16 p. $46 \mathrm{ff}$.

17 R. K. Newman (1989), p. 557. For Jordan see also W. Willoughby, vol. II, p. 1096. 


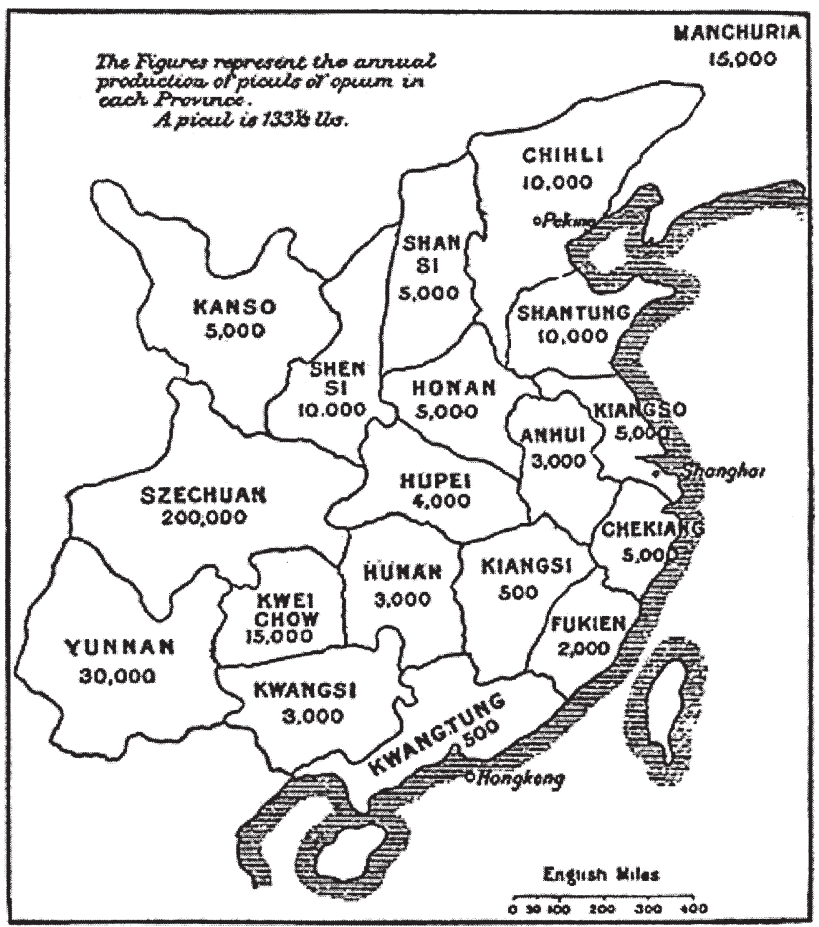

Map 17. Estimated Annual Opium Production per Chinese Province, 1908

Source: en.wikipedia.org (China and Opium). The sources used by the mapmaker(s) are unknown; this map probably belongs to the propaganda efforts of the British government. See also map. 18 below. The map is reproduced from the British Government White Paper, China, No. 1, 1908. Piculs are nearly equivalent to chests. The figures represent the annual production of piculs in each province. Added to this map is the comment of Lord Justice Fat: 'We English, by the policy we have pursued, are morally responsible for every acre of land in China which is withdrawn from the cultivation of grain and devoted to that of the poppy; so that the fact of the growth of the drug in China ought only to increase our sense of responsibility.'

taels to 16,000 taels per chest. ${ }^{18}$ And again: 'Moral anachronism' or not, under the umbrella of some British governmental institution as compensation for their "losses", the Sassoons got nearly 'a virtual monopoly in the other Far Eastern markets on which India itself was now having to rely'. ${ }^{19}$

18 During the financial year 1912-13 the Government of India received Rs. 43 million from opium taxes, etc. and the opium "merchants" (again the Sassoon family leading) Rs 35 million in the same year. Idem, p. 555. That was a profit on the purchasing in India only, not yet on the selling in China.

19 Idem, p. 557. During the last phase of this Indian-British-Chinese opium relation- 
In addition, the Shanghai Municipal Council, the governing body of the International Settlement in this city, failed to cooperate: 'from 1907 to 1913 the number of licensed opium shops in the Settlement increased from 87 to 560 and the revenue from licenses from 4,290 taels to 86,386 taels'. 20

In the power vacuum the British left behind, the USA and Japan entered. In particular, the new imperialist Japan started a raging opium war, more cruel than the former and extending over a large part of East Asia. Japan had a particular opium relation with the Middle East (Persia, Turkey) and could circumvent India and the British. It used other methods as well and copied the old imperialist game of importing opium to addict Chinese, it also renewed or refined this game by starting production of heroin and morphine on Chinese soil in the newly conquered parts of North China, Manchuria and Jehol, eventually with the assistance of some Chinese warlords.

... and his American heirs

To counteract the British dominance, the other new imperialist, the USA, was transformed from the main opium transporter and smuggler into the main provider of American missionaries agitating in an anti-opium mood. It also gave a demonstration of dollar diplomacy by granting Peking a large loan. However, the aim to replace the British as the most favorable commercial partner of the Chinese came too late: the Japanese were earlier, closer and more aggressive. The opium import in the USA became an increasing concern, and it gradually developed an anti-Japanese strategy. ${ }^{21}$ Its official anti-opium stand, however, was characterized by puzzling about whether the narcotics now imported on a large scale came from India, China or Japan.

In China, its main concern became another British heritage: the big problem of extraterritoriality, the autonomous political and legal power of the occupying Western powers in the International Settlement. Here the British and the French still dominated. During the extensive negotiations on the problems in the International Settlement in one conference

\footnotetext{
ship, it was the controversial Sir Edward Grey, the English Minister of Foreign Affairs (responsible for the outbreak of the First World War), who came to the conclusion 'that the right thing to do was to give in to David Sassoon ...' (Idem, p. 555).

20 W. Willoughby, vol. II, p. 1098 note 12.

${ }^{21}$ W. Walker III, p. $44 \mathrm{ff}$.
} 
after another, the American Willoughby proved to be the best expert on opium in the scene. He quotes a Japanese writer, Kawakami (1924), to explain his case:

Not only is China surrounded by opium-using countries, but she has within her own territories several centers of the opium trade. Foremost of these centers is Shanghai, followed by Hongkong, Canton, Macao, Harbin and Dairen. The International Settlement in Shanghai is said to have at least 500 opium stores, and the French Settlement 140. In the Foreign Settlements the import and sale of opium is not forbidden, and it is but natural that they should become favorite rendezvous of opium addicts and the vantage-ground from which crafty smugglers, both foreign and native, make inroads into the interior of China. ${ }^{22}$

Indeed, Willoughby's long discussion of all the international conferences shows the distressing reality that first and foremost the British and French governments obstructed the anti-opium measures with all possible tricks and lies in nurturing their extraterritoriality in China, while pretending at the same time that they were officially suppressing the opium business once and for all. Their interests coincided with those of the large opium dealers.

That did not concern the Americans. Their government mostly suggested that they were the best supporters of the Chinese case, while their private economic interests (American smuggling, banking, transportation through Hong Kong) continued as usual and without relevant government intervention.

Therefore, the story of the imported opium did not stop, but entered a quite new phase after 1911 as will be detailed in the next sections. The main practical elements of the story, how the Chinese involvement in the opium production and consumption rose and declined, will be described later.

We are left here to interpret the story of "China and its Imported Opium Problem". It seems as if there is still a cultural Opium Problem, which represents the most basic notions of the Western relations with China. One aspect of this is that we can find something of the truth only through the enemies of Britain. From the German side, for instance, the influential sociologist Max Weber wrote around 1905 the following statement which is difficult to find in present-day British or American literature:

22 W. Willoughby, vol. II, p. 1141 note 29. 
Opium, the narcotic perceived as of a specific Chinese nature, was still imported in modern times; it must be well-known that its acceptance in the country followed only after the fiercest opposition of the dominant elite was broken by a war from outside. ${ }^{23}$

This import was, therefore, not the result of a civilizing mission or something similar (if Germans had been involved), but only of naked conquest by a 'perfidious Albion' and its brutal, mainly American smugglers.

There are, however, quite different remarks found in the Anglo-Saxon historiography, probably thanks to Hosie's "positive approach" or British propaganda. The opportunity to demonstrate this is given by probably the most influential Western China watcher. Indeed, if we want to know how and why a new situation in the international relations emerged, we would receive 'only one recommendation: read John King Fairbank!' ${ }^{24}$ A wise advice because in assessing the impact of the Western opium assault on China, Fairbank (1907-1991) went, in fact, one step further than Sir Alexander Hosie.

After a study lasting many decades, he made the following remarkable

final proposition, that the most natural way to meet the West on equal terms was to follow a Chinese minority tradition which had more in common with Western ways of commerce and violent competition than with Chinese ideals of bureaucracy and harmonious compromise. For example, one peculiarly menacing aspect of the "Western Ocean" (Hsi-yang) people in the early contact at Canton was that their uncouth and greedy ways appealed to tendencies deeply latent among the Cantonese populace. The outright commercialism of the Western "barbarians" met a quick response among the shopkeepers in Hog Land behind the opulent ghetto of the Thirteen Factories. Once Indian opium was brought by the private merchants in the Country (local) trade from India, commercial greed fostered the growth of the opium trade on both sides. It became the great bilateral Sinoforeign joint enterprise of the nineteenth-century, and it succeeded far beyond anyone's fears or foresight. It requires only a modicum of imagination to see the Cantonese opium entrepreneur, who did his bit to usher China into modern international commerce, as the inheritor of the Chinese tradition that had much in common with the Western trading world. Some of the seemingly "foreign influences" of the Republican Revolution may turn

23 M. Weber, vol. 1, p. 519. Other remarks about opium can be found in Idem, p. 250, 296 notes, 506 and in Idem, vol. 2, p. 292. Weber and his colleagues were critical opponents of the British "market behavior". See for this H. Derks (2004), p. $102 \mathrm{ff}$. Max Weber never protested against the genocide German colonizers were committing in Southwest Africa against the Herrero at the time that he made this remark. This assault was loudly announced as part of a civilizing mission of the Germans in Africa.

${ }^{24}$ L. Blussé (2008), p. 100. 
out at second glance to have coincided with or grown from older Chinese trends that shared certain traits with the foreigners. ${ }^{25}$

One wonders what prevails in the mind of a brilliant historian who knows all the facts as described in detail in his many voluminous books. Anyway, there is no trace of a perception of the victim side of the Chinese or China. On the contrary, he equates at the start of a new episode in Chinese history (1911) 'a Chinese minority tradition' with a Western 'uncouth and greedy' commercialism. Now the victims truly become perpetrators.

Fairbank proposes that a mix between these two (and not the old 'harmonious', bureaucratic dominant tradition) was the basis of a Republican revolution. This mix became the new spirit for a new age which ultimately brought China 'on equal terms' with the West. In the end, Fairbank's final proposition implies that the catalyst for all this was, indeed, opium.

It is senseless to counteract Fairbank's moralistic 'final proposition' with another moral appeal. ${ }^{26}$ Hard political-economic facts are more than enough. First, the reliance here on the private merchant's opium business alone negates that two devastating opium wars and "peaceful" pressure exerted with a gun were needed to establish a so-called "free trade". This trade was, therefore, not free at all. In addition, it was no trade: the Chinese could not participate in it unless they stuck to the Western rules relative to the product (opium) and the handling of the profits and the organization of the trade (through foreign mediators, banks or shipowners), to avoid undermining the British-Indian import position.

It should have been realized, therefore, that this had nothing to do with "commercialism", which is by definition a peaceful mutual relationship between two parties on equal terms. Not only was it largely a military affair, the West (or, generally, all imperialists) had simply nothing on offer: throughout the 19th-century they had no products demanded in China; they came to conquer, to convert and to silence its victims by means of mass consumption of worthless opium, which had to be bought for high prices.

25 J. Fairbank (ed.), p. 8, 9.

26 Interestingly, Fairbank belonged to the so-called 'China Hands' with Theodore White, Owen Lattimore, Edgar Snow and others. They were foreign service officers, journalists, American scholars and advisers to the USA government during World War II and afterwards. They were soon accused by the McCarthy administration of being too soft on Communism, that they had helped to defeat Chiang Kai-shek and a lot more nonsense. See Wikipedia "China Hands". 
It should also have been obvious that all this had nothing to do with a 'great bilateral Sino-foreign joint enterprise' but instead a one-sided harsh assault. The prey of the assault was too big, however, for the British and other old imperialists. During a 50-year-long assault by the New Imperialists, they soon understood that fixing such a job was only possible by "Vietnamization" of the struggle: to keep Chinese fighting against Chinese and seek what could come out of it in order to renew its original grip (USA by supporting Chiang Kai-shek and Mao Zedong; Japan by setting up Chinese puppet regimes, cooperation with warlords, etc.).

And what about the 'quick response' to the Western assault of those 'Cantonese opium entrepreneurs' or some 'Chinese minority tradition', whatever that may be? It was largely through a Western-organised management that the West's program of creating a mass market for opium in China was executed. It cannot be denied that it succeeded far beyond anyone's fears or foresight' (although one can debate the degree to which this happened; see below consumption-production analysis). However, we cannot deny either that Chinese governments always remained highly motivated to suppress this opium habit as a Western import product (whether they were successful or not is another story). Mao Zedong and his CCP were no exception at the end of the Republican period and, indeed, continued a two centuries old tradition! ${ }^{27}$

The last comment on Fairbank's 'final proposition' concerns the product opium as handled in the British Crown colony Hong Kong until 1997. Fairbank could have checked what was left of his 'great bilateral Sinoforeign joint enterprise' in this British colony in China. Seven years after his text was written, a well-informed commentator wrote:

In the 1990s, Britain faces one of the most frightening and dangerous influxes of crime that it has ever encountered. Before Communist China takes over Hong Kong in 1997, the world's most ruthless criminal cartel will be stepping up its bid to take control of the underworld of Western society, and to spread within our culture like a criminal cancer. This cartel is the Chinese Triads - the yellow peril of the East, and now the West. ${ }^{28}$

27 On 22-12-2009 it was reported in my newspaper that "China" wanted to execute a British man (with the typical British name: Akmal Shaikh) because he imported four kilos of heroin. Gordon Brown has personally intervened, while the Foreign Office accused the Chinese authorities of not caring about the shaky mind of the smuggler: he must have been 'psychotic', 'unbalanced', 'misled by others' and so on. An old tradition in all respects!

28 Quoted in Y-K Chu, p. 1. 
That he is playing with the classical Western racism concerning the Yellow Danger must be clear after the previous chapter and that it is exaggerated will be discussed later. He rightly points, however, to the nasty effects of the British stay in China. Under its colonial responsibility, it offered a haven to a serious international criminal network based on opium and its derivatives, and now it is involved in the usual activities of local gangsters: gambling, prostitution, etc. ${ }^{29}$ Certainly in this extent, it would not have been possible under Chinese rule.

29 See also W. Walker III, p. 170-171 for how the American officials were misled by the British and Hong Kong government (including the nearby Portuguese colony of Macao). See for the British Hong-Kong opium history around 1900, the article of E. Sinn. 